\title{
Immunohistochemical Studies on Duodenum, Spleen and Liver in Mice: Distribution of Ferroportin and Prohepcidin in an Inflammation Model
}

\author{
Estudios Inmunohistoquímicos en Duodeno, Bazo e Hígado de Ratón: \\ Distribución de Ferroportina y Prohepcidina en un Modelo de Inflamación
}

María Cecilia D’Anna; Gisela Giorgi \& Marta Elena Roque

D'ANNA, M. C.; GIORGI, G. \& ROQUE, M. E. Immunohistochemical studies on duodenum, spleen and liver in mice: distribution of ferroportin and prohepcidin in an inflammation model. Int. J. Morphol., 29(3):747-753, 2011.

SUMMARY: Duodenum, spleen and liver have a crucial role in iron balance on the whole organism and are the major sites of Ferroportin (FPN) expression. Specific regulations between FPN and hepcidin are responsible for changes seen in physiopathological conditions such as inflammation. We studied in vivo effects of turpentine oil-induced acute inflammation on FPN expression, and its relation with prohepcidin and iron mobilization. Immunohistochemical procedures were performed using rabbit anti-mouse FPN and prohepcidin antibodies with goat-labeled polymer-HRP anti-rabbit (DAB) as secondary antibody. Plasma and tissular iron were also studied. Our results showed a notable expression and redistribution of duodenal FPN to basolateral membrane in turpentine-treated mice, compared with supranuclear and the weak basolateral expression observed in healthy mice. Red pulp macrophages of healthy mice showed FPN-hemosiderin co-localization, compared with turpentine-treated mice which showed lack of FPN. In liver of healthy mice, FPN was seen in Kupffer cells, whereas in turpentine-treated mice decreased. In addition, we observed an increment of hepatic prohepcidin with a significant hypoferremia. Our findings demonstrated that acute inflammation induced a differential distribution of FPN, showing a cell type specific response. In macrophages, increased hepatic prohepcidin induced degradation of FPN, resulting in hypoferremia. In enterocytes, the redistribution observed of duodenal FPN reflects a different regulation in this tissue. The observed response of the proteins studied may be part of a cyclical pattern of systemic effects of acute inflammation on mouse tissue.

KEY WORDS: Iron; Mobilization; Macrophages; Enterocytes.

\section{INTRODUCTION}

Iron is an essential nutrient for growth and development for all living organisms, particularly for mammalian erythropoiesis (Ganz, 2006). Since it is known that iron excess can lead to the production of oxygen free radicals, important homeostatic mechanism must prevent excessive iron absorption in duodenum and must regulate the rate of iron release from macrophages involved in recycling.

Another reason why iron must be tightly controlled is resistance to infection. The acute phase response to infection is characterized by a number of changes in iron metabolism that includes a decline in serum iron turnover, sequestration of the metal in the Reticulo Endothelial System
(RES), and in some cases a decrease in iron absorption (Yeh et al., 2003). In inflammatory conditions, a diversion of iron traffic occurs from circulation to storage sites to minimize the availability of this nutrient to pathogens (Jurado, 1997). These changes in iron metabolism contribute to the development of anemia of inflammation, in which the pathogenic mechanisms that cause this disorder are not well understood (Weiss \& Goodnough, 2005). It is thought to involve shortened erythrocyte lifespan with inadequate erythropoietic compensation.

The coordination and regulation of all these processes involve iron metabolism proteins. Hepcidin is the major iron regulator that limits iron absorption and iron release from 
macrophages (Ganz). It seems to have a significant role during inflammation by inducing hypoferremia. proinflammatory cytokines as IL-6 are a prominent inducer of hepcidin in inflammatory conditions, through a STAT-3 dependent transcriptional mechanism (Verga Falzacappa $e t$ al., 2007).

To achieve its function, hepcidin binds to ferroportin (FPN), the only known iron exporter in enterocytes and macrophages, inducing its internalization, ubiquitinization and its subsequent degradation (Nemeth et al., 2004). As a consequence, in the presence of hepcidin, iron efflux from FPN-expressing cells is greatly decreased, leading to hypoferremia, since iron cannot release from the cell (Rivera et al., 2005). Since it is known that FPN is the main responsible for iron exportation from RES compartment and from enterocytes, several authors have studied its regulation in inflammation (Yang et al., 2002; Sheikh et al., 2007).

However, tissue specific differences in FPN regulation and differential effects of hepcidin on iron tissues show that the adaptive response to inflammation is not entirely clear (Chaston et al., 2008). Although there are studies about FPN regulation in macrophages of the RES in acute inflammation, its effects on duodenal FPN are less conclusive.

In order to determine the cell-type specific response of acute inflammation on FPN expression on iron relatedtissues, we develop an in vivo model to assess the distribution of FPN and its relation with prohepcidin.

\section{MATERIAL AND METHOD}

Animals. Adult female mice (CF1) $(30 \pm 5 \mathrm{~g})$ were bred at the animal facility of the Universidad Nacional del Sur. The animals were kept in cages at controlled room temperature and humidity and were fed throughout on a standard diet with access to water ad libitum, under standard conditions: a $12 \mathrm{~h}$ light-dark period. The procedures followed are in line with the Guide for the Care and Use of Laboratory Animals. Prior to the initiation of this study, the protocol was approved by the Assessor Committee of Animal Care and Use of the Universidad Nacional del Sur.

Experimental Design . Adult mice (CF1) were divided into two groups (6 mice per group): (a) Turpentine-treated mice receiving turpentine oil intraperitoneally $(150 \mu \mathrm{l})$ (Sigma Chemical Co.) and (b) healthy mice receiving saline solution $(0.9 \% \mathrm{NaCl})$. Mice were subjected to blood controls, before turpentine or saline solution administration. Animals were anesthetized with diethyl ether for blood collection. Samples were collected throughout the study from the retro-orbital venous plexus.

Tissue Harvestation at Necropsy. A subset of each group of animals $(n=3)$, were sacrificed by cervical dislocation. The duodenum, spleen and liver from both healthy and turpentine-treated mice were removed under sterile conditions by abdominal incision and fixed in $10 \%$ buffered formalin. Tissues were embedded in paraffin and sections of $5 \mu \mathrm{m}$ were obtained.

Antibodies. Primary antibodies against mouse FPN were raised against a peptide corresponding to the $\mathrm{C}$-terminus of FPN (GPDEKEVTDENQPNTS), kindly provided by Bruno Galy, from the European Molecular Biology Laboratory (EMBL), Germany. Prohepcidin immunodetection was performed with anti-mouse prohepcidin (Alpha Diagnostic). Rabbit anti-mouse L-chain Ferritin (RbaMoLF) were kindly provided by Paolo Santambrogio from Istituti di Ricovero e Cura a carattere scientifico, Italy. Goat-labeled polymer-HRP anti-rabbit Envision+System (DAB) (Dako Cytomation) was used as secondary antibody.

Immunohistochemistry technique. Tissue samples from healthy and turpentine-treated mice were post-fixed by immersion in fresh fixative solution (10\% neutrally buffered formalin, $\mathrm{pH}$ 7.2) and embedded in paraffin. Sections of 5 $\mu \mathrm{m}$ were obtained and mounted on glass slides. Before labeling, sections were deparaffinized in xylene and rehydrated in a graded series of ethanol baths. Endogenous peroxidase activity in deparaffinized sections was blocked with $\mathrm{H}_{2} \mathrm{O}_{2} 3 \%$. Sections were then incubated in phosphate buffered saline (PBS), $\mathrm{pH} \mathrm{7.1,} \mathrm{for} 10$ minutes at room temperature. Incubation with the primary antibody diluted into phosphate-buffered saline ( $\mathrm{pH}: 7.1)$ was carried out in a wet chamber for one hour at room temperature for FPN, and overnight at $4^{\circ} \mathrm{C}$ for prohepcidin and L-ferritin immunodetection. Dilutions of antibodies were as follows: anti-FPN (1:500), anti-prohepcidin (1:100) and anti L-ferritin (1:1000). Following incubation with the primary antibody, tissues were washed with PBS, incubated with a goat antirabbit IgG peroxidase coupled secondary antibody for one hour at room temperature, and then re-washed with PBS. Subsequent localization of proteins was revealed by reaction with 3'-diaminobenzidine tetrahydrochloride (DAB) solution. Sections were then counter-stained with Harris hematoxilin. Finally, sections were dehydrated in ethanol and xylene and mounted on cover slips. Negative controls included incubation with PBS without the primary antibody. Immunostaining was analyzed using an Olympus BX51 microscope, equipped with $\mathrm{x} 10, \mathrm{x} 20$ and $\times 40$ dry objectives, and an x100 oil immersion objective. Digital images were obtained with an Olympus C7070 camera. 
Plasma and Tissular iron. In plasma samples from healthy and turpentine-treated mice, iron levels were detected by colorimetric ferrozine-based assay (Roche/Hitachi) at: $3 \mathrm{hs}$, $16 \mathrm{hs}, 24 \mathrm{hs}$ and $48 \mathrm{hs}$.

Liver iron content was determined after acid digestion of hepatic samples using nitric acid 35\% and followed by iron quantification with colorimetric ferrozine-based assay.

To determine iron store, Prussian blue iron staining was performed in sections of mouse duodenum, spleen and liver, following the manufacturer's instructions. Deparaffinized tissue sections were incubated in $2 \% \mathrm{HCl}$ containing $10 \%$ potassium ferrocyanide for $15 \mathrm{~min}$, washed and counterstained with Nuclear Red before visualization. Some of the spleen sections were treated with anti-FPN and anti-L-ferritin antibodies using the immunohistochemistry technique followed by Prussian blue iron staining, in order to determine the presence of hemosiderin deposits in both FPN and L-ferritin-positive cells. These sections were counterstained with Nuclear Red.

Statistical analysis. In all mouse experiments, at least 6 mice were tested individually. Data of iron levels and hematological parameters were analyzed by Student's t-test. The level of statistical significance was set at $\mathrm{P}<0.05$. All values are expressed as mean \pm SD.

\section{RESULTS}

\section{Ferroportin Expression}

Duodenal tissue. In healthy mice, FPN was detected mainly inside enterocytes, localized immediately above the nucleus on the apical side, with slight basolateral expression (Fig. 1A). Interestingly duodenal FPN expression changed in turpentine-treated mice, showing not only an increase but also redistribution along the basolateral membrane throughout villous enterocytes (Figs. 1B, 1C).

Splenic tissue. Splenic FPN expression in healthy mice was particularly marked in red pulp macrophages surrounding nodules of white pulp, without expression in white pulp (Fig. 1E). Immunoreactivity in the red pulp was observed both cytoplasmically and on the plasma membrane of macrophages. As expected, in red pulp, a large number of macrophages were stained for FPN and some of them also had hemosiderin (Fig. 1E). Sections of spleen of turpentine-treated mice, showed a decrease in FPN staining of splenic macrophages compared with healthy mice (Fig. 1F). In this condition, most of macrophages were negative for FPN and positive for hemosiderin.
Hepatic tissue. FPN expression in liver of healthy mice was limited to cells-identified as Kupffer cells on the basis of their cell morphology, where expression was found to be cytoplasmic and also at the plasma membrane (Fig. 1H). Turpentine treatment resulted in down-regulation of FPN expression observing only few discrete Kupffer cells positive for FPN (Fig. 1I).

Hepatic prohepcidin expression. Hepatic lobules of healthy mice were heterogeneous with respect to prohepcidin immunoreactivity. Within a hepatic lobule, prohepcidin expression was predominantly located in central veins being only few positive in periportal zones (Fig. 1K, 1L).

In inflammation, we noted an increase in the number of hepatocytes that express prohepcidin, noting expression in all hepatic stroma, including expression near blood vessels (Figure 1M). In healthy mice intercellular differences existed between Prohepcidin positive cells: while most hepatocytes were strongly positive for prohepcidin others displayed only faint staining or were totally unreactive for prohepcidin. Kupffer cells, endothelial cells, lacked of prohepcidin immunoreactivity.

\section{Iron Distribution}

Duodenal tissue. In duodenum, enterocytes of healthy mice were positive for L-ferritin, noting expression both along the villi and in the crypts. At the subcellular level, cytoplasmic L-ferritin expression was observed and in some sections near the nucleus. Notably, not all the enterocytes were positive, with few less reactive for L-ferritin (Fig. 1D). In duodenum of turpentine-treated-mice, hemosiderin was undetectable (Fig. 1C). This pattern of expression was seen both in healthy and turpentine-treated mice.

Splenic tissue. Immunohistochemical assays revealed that L-ferritin is highly expressed in spleen of both healthy and turpentine-treated mice (Fig. 1G). As expected, in the red pulp, a large number of macrophages were stained for Lferritin and some of them also had hemosiderin (Fig. 1G). Hemosiderin was mainly found in red pulp (Fig. 1G). In white pulp, the cells stained for L-ferritin were few macrophages in the mantle zone and in marginal zone, most of them were negative for hemosiderin. We have not noted differences between healthy and turpentine-treated mice.

Hepatic tissue. There was no discernible hemosiderin in liver of healthy and turpentine-treated mice neither hepatocytes nor Kupffer cells. L-ferritin expression was limited to hepatocytes, the pattern of expression along the tissue was associated with vascular sites, showing intense staining near central zones of the hepatic lobules (Fig. 1J). 

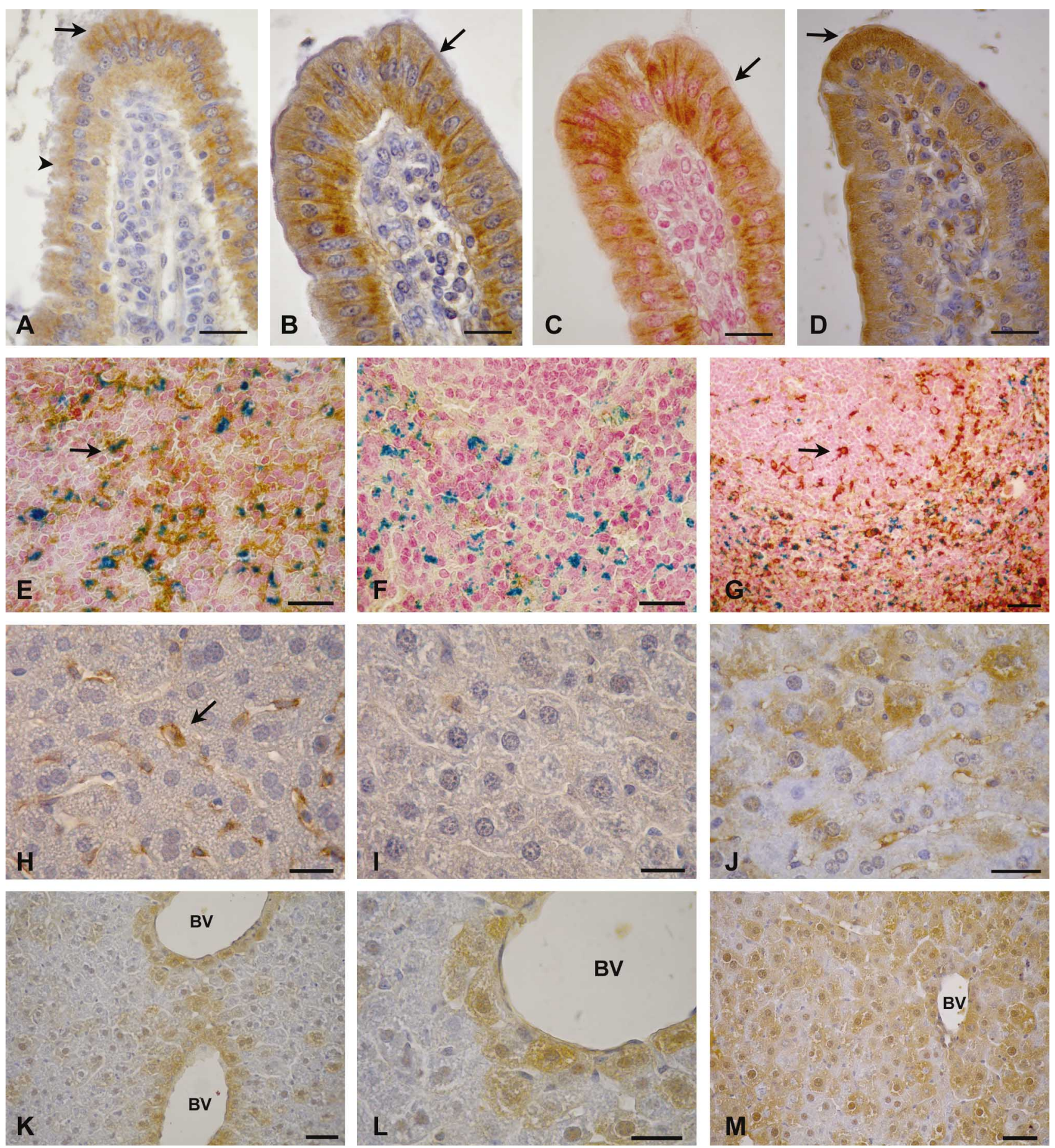

Fig. 1. Ferroportin in duodenum, spleen and liver of healthy and turpentine-treated mice. A) Duodenum of healthy mice showing supranuclear (arrowhead) and slight basolateral expression (arrow); B) Duodenum of turpentine-treated mice showing high basolateral expression (arrow); C) Duodenum of turpentine-treated mice showing high basolateral expression (arrow), without hemosiderin; D) Duodenum showing cytoplasmic L-ferritin expression in enterocytes (arrow); E) Splenic tissue of healthy mice showing FPN on macrophages of the red pulp and co-localization with hemosiderin (arrow); F) Red pulp of turpentine-treated mice showing lack of FPN and hemosiderin (blue) on macrophages; G) Splenic tissue showing L-ferritin expression on macrophages (arrow) and co-localization with hemosiderin (arrow); H) Hepatic tissue of healthy mice showing FPN on Kupffer cells (arrow); I) Hepatic tissue of turpentine-treated mice showing lack of FPN expression; J) Hepatic tissue showing L-ferritin expression on hepatocytes (arrow) and on Kupffer cells; K) Hepatic tissue of healthy mice showing expression near blood vessels (arrows); L) Hepatocytes of healthy mice showing cytoplasmic expression (arrow); M) Hepatic tissue of turpentine-treated mice showing high expression in all stroma. Tissue sections prepared as described in Materials and Methods were stained with polyclonal rabbit anti-FPN antibody (A, B, C, E, F, H, I); anti-L-ferritin antibody (D, G, J); anti-Prohepcidin antibody (K, L, M). BV: blood vessel. Scale Bars: $20 \mu \mathrm{m}$. 
We could also observe some Kupffer cells positive for L-ferritin and not associated with vascular sites (Fig. 1J). Hepatic iron of turpentine-treated mice did not change compared with healthy mice $(12.1 \pm 2.6$ vs. $7.0 \pm 4.0 \mu \mathrm{mol} / \mathrm{g}$ dry weight $)$.

Plasma Iron. Plasma iron levels at both $16 \mathrm{hs}$ and $24 \mathrm{hs}$ in turpentine-treated mice revealed a significant decrease $(162 \pm 25 \mu \mathrm{g} / \mathrm{dL}$ at $16 \mathrm{hs} ; 116 \pm 10 \mu \mathrm{g} / \mathrm{dL}$ at $24 \mathrm{hs})$ compared with that observed in healthy mice $(280 \pm 35 \mu \mathrm{g} / \mathrm{dL})$ (Fig. 2).

\section{DISCUSSION}

Our model of acute inflammation, which causes a subsequent systemic induction of acute phase response, was used to better understand the role of FPN and hepcidin in iron related tissues when iron metabolism is altered.

It is well known that hepcidin regulates iron distribution by controlling FPN expression (Ganz). The best studied cell type is the macrophage, where evidence supports direct inhibitory effects of hepcidin on FPN levels (Delaby et al., 2005). The low levels of FPN expression seen in acute inflammation in spleen and liver supports this inhibitory effect of hepcidin, impairing iron efflux and causing hypoferremia. As regards macrophages, the reduction of splenic and hepatic FPN observed in acute inflammation may facilitate iron retention and accumulation, explaining the rapid and marked hypoferremia observed (Yang et al.). Therefore, the reduction in plasma iron levels is strong evidence that there was a decrease in iron exportation.

Iron retention occurs if there is iron release blockage. However, we could detect only little or no parenchyma hepatic iron at all. Additionally, in adult mice, the spleen appears as the major site of iron storage, containing more iron than the liver, and this iron is partially associated with hemosiderin being probably strainspecific (Cesta, 2006). Therefore, high levels of hemosiderin observed in spleen of healthy mice under our experimental conditions could hamper the definition of changes in iron deposition.

Changes seen in splenic and hepatic FPN may result from a signal generated by hepcidin-FPN interaction (Nemeth et al.). Taking into account the critical role of this regulator, we focused our study on the assessment of Prohepcidin expression

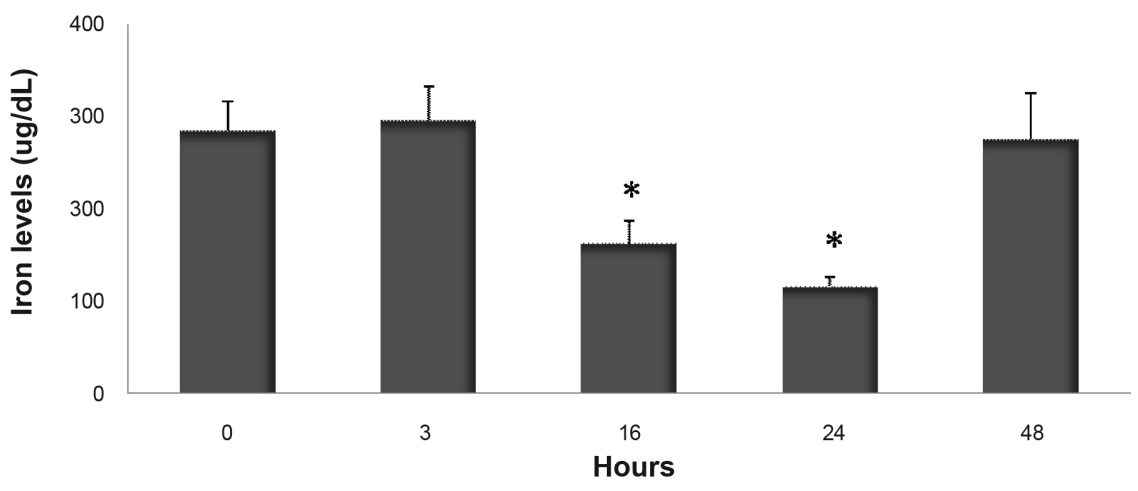

Fig. 2. Plasma iron during acute inflammation. Values are means $\pm \mathrm{SD}(* \mathrm{P}<0.05$, analyzed by Student's t-test). and localization both in healthy and turpentine- treated mice.

In our study, prohepcidin localization in hepatocytes near blood vessels in healthy mice was in line with what would be expected for a secreted molecule. This result is consistent with that obtained by Wallace et al. (2006), who reported prohepcidin localization in organelles, particularly Golgi apparatus, suggestive of proteins being accumulated in the secretory pathway prior to receiving a signal for secretion (Veuthey et al., 2008). In fact, under our experimental conditions, turpentine treatment lead to an increase in prohepcidin expression levels.

Duodenum is one of the major sites of FPN expression, and as such it would be expected to respond in a similar fashion to splenic and hepatic FPN (Abboud \& Haile, 2000; D’Anna et al., 2009). However, duodenal FPN showed a different pattern of expression by acute inflammation. Paradoxically, several studies showed that FPN levels were either unchanged or even increased, although high hepcidin levels were found in all the cases (Chaston et al.).

Unexpectedly, we clearly demonstrated a strong expression and redistribution of duodenal FPN by acute inflammation, showing that the mechanisms of intestinal iron regulation are different at least under our experimental conditions. Apparently, different signals could be involved in FPN regulation being cell-type specific. A finding worth noting concerns the redistribution of FPN to basolateral membrane, even with high levels of prohepcidin.

The basis for the differential effect of hepcidin in duodenal tissue is less clear. Previous studies have 
shown that the effect of hepcidin on serum iron levels is dose-dependent (Rivera et al.). Therefore, we could explain the increased levels of duodenal FPN by the fact that duodenum simply requires a higher concentration of hepcidin, as occurs in chronic inflammation.

We suggest that there are tissue-specific differences in the response to hepcidin where not only temporal and quantitative differences exist in hepcidin action on iron tissues, but also the stimuli itself to increase this iron regulator. There is clear evidence that when it needs to block iron absorption as inflammation, FPN only decreases in tissues which are more compromised with iron metabolism since RES recycles a large amount of iron daily (Knutson \& Wessling-Resnick). Thus, we suggest that macrophages could be more sensitive than enterocytes to a hepcidin challenge and these cells require a more significant change in hepcidin levels to respond as RES.
Finally, the molecular pathways in acute inflammation include high prohepcidin levels which cause degradation of reticuloendothelial FPN resulting in hypoferremia. To cause a similar effect on duodenum, the signal should persist. We suggest that the regulatory signal that affected reticuloendothelial FPN was hepcidin. In the case of duodenal FPN, such response may be caused by hypoferremia. Taken all together, the observed response of the proteins studied may be part of a cyclical pattern of systemic effects of acute inflammation on mouse tissues.

\section{ACKNOWLEDGEMENTS}

We thank Drs. Matthias Hentze and Bruno Galy for generously providing FPN antibody reagents, and also thank Dr. Paolo Santambrogio for providing L-ferritin antibody.

D’ANNA, M. C.; GIORGI, G. \& ROQUE, M. E. Estudios inmunohistoquímicos en duodeno, bazo e hígado de ratón: distribución de ferroportina y prohepcidina en un modelo de inflamación. Int. J. Morphol., 29(3):747-753, 2011.

RESUMEN: El duodeno, bazo e hígado desempeñan un rol clave en el balance de Fe del organismo y son los mayores sitios de expresión de ferroportina (FPN). Regulaciones específicas entre FPN y hepcidina son las responsables de los cambios observados en condiciones fisiopatológicas como la inflamación. Nuestro objetivo fue estudiar los efectos in vivo de la inflamación aguda inducida con turpentina sobre la expresión de FPN y su relación con prohepcidina y la movilización de hierro. Los procedimientos inmunohistoquímicos fueron desarrollados utilizando anticuerpos anti FPN y prohepcidina de ratón, desarrollados en conejo y un polímero conjugado con anticuerpos secundarios anti conejo desarrollado en cabra (HRP-DAB). Se evaluaron los niveles de Fe plasmático y tisular. Nuestros resultados mostraron una clara expresión y redistribución de FPN duodenal hacia la membrana basolateral en ratones tratados con turpentina, con respecto a la expresión perinuclear y leve expresión basolateral observada en ratón sano. Macrófagos de la pulpa roja esplénica mostraron co-localización de FPN y hemosiderina, comparado con la ausencia de expresión en ratón tratado con turpentina. En hígado de ratón sano, se observó expresión de FPN en células de Kupffer, mientras que en ratón tratado con turpentina la expresión fue menos evidente. Además, observamos un aumento en la expresión de prohepcidina hepática con una hipoferremia significativa. Nuestros resultados demostraron que la inflamación aguda indujo una distribución diferencial de FPN, mostrando una respuesta específica del tipo celular. En macrófagos, el aumento de prohepcidina hepática indujo degradación de FPN, resultando en hipoferremia. En enterocitos, la redistribución observada de FPN duodenal, refleja una regulación diferente en este tejido. La respuesta observada de las proteínas estudiadas podría ser parte de un patrón cíclico de efectos sistémicos de la inflamación aguda en tejidos murinos.

PALABRAS CLAVE: Hierro; Movilización; Enterocitos; Macrófagos.

\section{REFERENCES}

Abboud, S. \& Haile, D. J. A novel mammalian iron-regulated protein involved in intracellular iron metabolism. J. Biol. Chem., 275(6):19906-12, 2000.

Cesta, M. F. Normal structure, function, and histology of the spleen. Toxicol. Pathol., 34(5):455-65, 2006.

Chaston, T.; Chung, B.; Mascarenhas, M.; Marks, J.; Patel, B.; Srai, S. K. \& Sharp, P. Evidence for differential effects of hepcidin in macrophages and intestinal epithelial cells. Gut, 57(3):374-82, 2008.
D’Anna, M. C.; Veuthey, T. V. \& Roque, M. E. Immunolocalization of ferroportin in healthy and anemic mice. J. Histochem. Cytochem., 56(1):9-16, 2009.

Delaby, C.; Pilard, N.; Gonçalves, A. S.; Beaumont, C. \& Cannone-Hergaux, F. Presence of the iron exporter ferroportin at the plasma membrane of macrophages is enhanced by iron loading and down-regulated by hepcidin. Blood, 106(12):3979-84, 2005.

Ganz, T. \& Nemeth, E. Regulation of iron acquisition and 
D'ANNA, M. C.; GIORGI, G. \& ROQUE, M. E. Immunohistochemical studies on duodenum, spleen and liver in mice: distribution of ferroportin and prohepcidin in an inflammation model. Int. J. Morphol., 29(3):747-753, 2011

iron distribution in mammals. Biochim. Biophys. Acta, 1763(7):690-9, 2006.

Jurado, R. L. Iron, infections and anemia of inflammation. Clin. Infect. Dis., 25(4):888-95, 1997.

Knutson, M. D. \& Wessling-Resnick, M. Iron metabolism in the reticuloendothelial system. Crit. Rev. Biochem. Mol., 38(1):61-88, 2003.

Nemeth, E.; Tuttle, M. S.; Powelson, J.; Vaughn, M. B.; Donovan, A.; Ward, D. M.; Ganz, T. \& Kaplan, J. Hepcidin regulates cellular iron efflux by binding to ferroportin and inducing its internalization. Science, 306(5704):2090-3, 2004.

Rivera, S.; Nemeth, E.; Gabayan, V.; Lopez, M. A.; Farshidi, D. \& Ganz, T. Synthetic hepcidin causes rapid-dose dependent hipoferremia and is concentrated in ferroportincontaining organs. Blood, 106(6):2196-9, 2005.

Sheikh, N.; Dudas, J. \& Ramadori, G. Changes of gene expression of iron regulatory proteins during turpentine oil-induced acute-phase response in the rat. Lab. Invest., 87(7):713,25, 2007.

Verga Falzacappa, M. V.; Vujic Spasic, M.; Kessler, R.; Stolte, J.; Hentze, M. W. \& Muckenthaler, M. U. STAT3 mediates hepatic hepcidin expression and its inflammatory stimulation. Blood, 109(1):353-8, 2007.

Veuthey, T.; D’Anna, M. C. \& Roque, M. E. Role of the kidney in iron homeostasis: renal expression of Prohepcidin, Ferroportin and DMT1 in anemic mice. Am. J. Physiol. Renal Physiol., 295(4):F1213-21, 2008.

Wallace, D. F.; Summerville, L.; Lusby, P. E. \& Subramaniam, V. N. Prohepcidin localizes to the Golgi compartment and secretory pathway in hepatocytes. $J$. Hepatol., 43(4):720-8, 2006.

Weiss, G. \& Goodnough, L. T. Anemia of chronic disease. N. Engl. J. Med., 352(10):1011-23, 2005.

Yang, F.; Liu, X. B.; Quinones, M.; Melby, P. C.; Ghio, A. \& Haile, D. J. Regulation of Reticuloendothelial Iron Transporter MTP1 (Slc11a3) by Inflammation. J. Biol. Chem., 277(2):39786-91, 2002.

Yeh, K.; Yeh, M. \& Glass, J. Hepcidin regulation of ferroportin 1 expression in the liver and intestine of the rat. Am. J. Physiol. Gastrointest. Liver Physiol., 286(3):385-94, 2003.

\section{Correspondence to: Marta Elena Roque Laboratory of Human Physiology Department of Biology, Biochemistry and Pharmacy Universidad Nacional Del Sur San Juan 670, 8000 Bahía Blanca ARGENTINA}

Tel.: +542914595100

Fax: +542914595130

Email: mroque@uns.edu.ar

Received: 04-04-2011

Accepted: 31-05-2011 